Article

www.mdpi.com/journal/agriculture

\title{
Multi-Location Study of Soil Enzyme Activities as Affected by Types and Rates of Manure Application and Tillage Practices
}

\author{
Veronica Acosta-Martinez ${ }^{1, *}$, Maysoon M. Mikha ${ }^{2}$, Karamat R. Sistani ${ }^{3}$, Phillip W. Stahlman ${ }^{4}$, \\ Joseph G. Benjamin ${ }^{2}$, Merle F. Vigil ${ }^{2}$ and Richie Erickson ${ }^{5}$
}

1 Cropping Systems Research Laboratory, USDA-ARS, 3810 4th Street, Lubbock, TX 79415, USA

2 Central Great Plains Research Station, USDA-ARS, 40335 County Road GG, Akron, CO 80720 , USA; E-Mails: maysoon.mikha@ars.usda.gov (M.M.M.); joseph.benjamin@ars.usda.gov (J.G.B.); merle.vigil@ars.usda.gov (M.F.V.)

3 Animal Waste Management Research Unit, USDA-ARS, 230 Bennett Lane, Bowling Green, KY 42104, USA; E-Mail: karamat.sistani@ars.usda.gov

4 Agricultural Research Center-Hays, Kansas State University, 1232 240th Avenue, Hays, KS 67601, USA; E-Mail: stahlman@ksu.edu

5 The Institute of Environmental and Human Health (TIEHH), Texas Tech University, Reese Technology Center Building 555, 1207 Gilbert Drive, Lubbock, TX 79416, USA; E-Mail: richie.erickson@tiehh.ttu.edu

* Author to whom correspondence should be addressed; E-Mail: veronica.acosta-martinez@ars.usda.gov; Tel.: +1-806-723-5233; Fax: +1-806-723-5272.

Received: 19 November 2011; in revised form: 2 December 2011 / Accepted: 5 December 2011 / Published: 9 December 2011

Abstract: Significant amounts of manure are produced in the USA; however, information on the changes in ecosystem services related to soil biogeochemical cycling for agroecosystems supported with organic amendments such as manure is limited. A multi-location field study was initiated in Colorado (CO), Kansas (KS) and Kentucky (KY), USA in loam soils to evaluate the effects of manure and tillage practices on enzyme activities that are key to biogeochemical cycling such as $\beta$-glucosidase ( $\mathrm{C}$ cycling), $\alpha$-galactosidase ( $\mathrm{C}$ cycling), $\beta$-glucosaminidase ( $\mathrm{C}$ and $\mathrm{N}$ cycling) and phosphomonoesterases (P cycling). The treatments were as follows: (i) two years of beef manure applications to a fine sandy loam at different rates (control: 0 , low: $34 \mathrm{~kg} \mathrm{~N} \mathrm{ha}^{-1}$ and high: $96 \mathrm{~kg} \mathrm{~N} \mathrm{ha}^{-1}$ ) and tillage practices in $\mathrm{CO}$; (ii) three years of beef manure applications to a silt loam at different rates (0, low: $67 \mathrm{~kg} \mathrm{~N}^{-1}$ and high: $134 \mathrm{~kg} \mathrm{~N}^{-1}$ ) and tillage practices in $\mathrm{KS}$ and; (iii) three years of poultry and dairy manure applications to a silt loam with different 
tillage practices at the same rate $\left(403 \mathrm{~kg} \mathrm{~N} \mathrm{ha}^{-1}\right)$ in $\mathrm{KY}$. Tillage practices (none vs. conventional) had no effect on the enzyme activities. Principal Component Analyses (PCA) grouped all enzyme activities with the high beef manure application rate after the first year in $\mathrm{CO}$ at $0-5 \mathrm{~cm}$. By the second year, the low and high beef manure rates differed in enzyme activities for the KS soil with no difference between the low rate and control in CO. Since the first year of the KY study, acid phosphatase activity was greater in the poultry treated soil compared to dairy or the control; whereas, $\mathrm{C}$ cycling enzyme activities were similar in soil treated with dairy or poultry manure. For all studies, PCAs for soil samples from 5-10 $\mathrm{cm}$ depth did not reveal treatment separation until the second year, i.e., only high application rate differed from the other treatments. Results of the study indicated significant responses in $\mathrm{C}$ and $\mathrm{P}$ cycling enzyme activities to manure applications within two years, suggesting potential benefits to soil biogeochemical cycling essential for the productivity of agroecosystems supported with organic fertilizers.

Keywords: broiler litter; poultry manure; dairy manure; beef manure; corn; tillage; enzyme activities; biogeochemical cycling; soil quality

\section{Introduction}

Across the USA, some farmlands have lost a portion of its topsoil through wind and water erosion induced by decades of intensive cultivation. Several studies have shown that soil degradation is a result of soil organic matter (SOM) lost through increased soil disturbance and decomposition $[1,2]$. Decreases in SOM can alter the soil microbial ecology, nutrient cycling and other soil properties leading to decreases in soil quality and thus productivity. Applying organic amendments, such as manure, to agroecosystems as the nutrient source is a management practice that can increase SOM and improve the nutrient status of the soil $[3,4]$; however, different types and rates of manure application can have a different impact on soil biogeochemical cycling and SOM dynamics within the initial years depending on soil type and climatic conditions. Positive influence of manure applications occur due to the changes in soil microbial communities [5], strongly affecting the soil's potential for enzyme-mediated substrate catalysis [6] that control soil nutrient availability and SOM quality and quantity. Therefore, the assessment of enzymes involved in $\mathrm{C}, \mathrm{N}$, and $\mathrm{P}$ cycling may provide an indication of the substrate quality applied with various type of manure, as they are substrate-specific, and of the changes in soil biogeochemical cycling.

The glycosidases are a group of $\mathrm{C}$ cycling enzymes that should be investigated as a function of manure applications as they play a key role in the breakdown of low molecular weight of carbohydrates producing sugars; the main source of energy for soil microorganisms. The $\beta$-glucosidase activity, the most predominant glycosidase in soil, is involved in the last limiting step of cellulose degradation. The $\alpha$-galactosidase, also known as melibiase, catalyzes the disaccharides hydrolysis, $\alpha$-D-galactopyranosides, in soils. The $\beta$-glucosaminidase is a key enzyme involved in the hydrolysis of $N$-acetyl- $\beta$-D-glucosamine residues from the terminal non-reducing ends of chitooligosaccharides [7]. The $N$-acetyl- $\beta$-D-glucosamine hydrolysis considered to be important for soil $\mathrm{C}$ and $\mathrm{N}$ cycling due to 
its role in converting chitin to amino sugars, a major source of easily mineralizable $\mathrm{C}$ and $\mathrm{N}$ in humid soils [8]. The $\beta$-glucosaminidase activity has been positively correlated with cumulative $\mathrm{N}$ mineralized in soils [8,9], microbial biomass $\mathrm{C}$ and $\mathrm{N}$, and with fungal populations, as indicated by a fungal

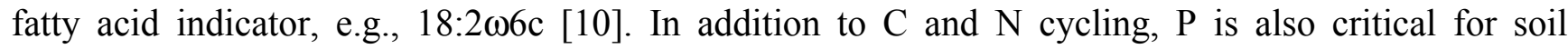
biogeochemical cycling and $\mathrm{P}$ is the second-most limiting nutrient after $\mathrm{N}$ in agricultural production. However, information on the effects of different types of manures in soil $\mathrm{P}$ cycling enzymes, i.e., phosphomonoesterases, that catalyze the hydrolysis of a variety of $\mathrm{P}$ sources important in plant nutrition is scarce [11].

To increase our understanding of biogeochemical cycling and of SOM dynamics in agricultural eroded land managed with manure, we need to investigate enzyme activities across different management practices and weather patterns. Therefore, we evaluated the enzyme activities of $\beta$-glucosidase, $\alpha$-galactosidase, $\beta$-glucosaminidase and phosphomonoesterases (acid or alkaline phosphatase), as influenced by conventional and no-tillage and by manure type and rates of applications compared to non-treated soil (or treated with commercial fertilizer) in field plots with loam soils in three USA States: CO, KS and KY.

\section{Materials and Methods}

This study was conducted in loam soils across the States of CO, KS and KY, USA. The three study-sites had no previous history of manure application. The rates of manure application for these studies were selected based on conventional commercial fertilizer associated with each crop at each location used by producers. The manure was applied every year on the basis of the manure's organic $\mathrm{N}$ content. At $\mathrm{CO}$ and KY sites, conducted in USDA-ARS research farms, the manure was provided by the nearby commercial feedlot (less than $10 \mathrm{~km}$ ). At KS site, the manure was provided by the animal research unit located at the same research center where the experiment was conducted (Agricultural Research Center in Hays KS). At each site, the experimental design was a randomized split-plot with three replications, with tillage as the main plot and the nutrient source (manure or commercial fertilizer) as the split plot.

\subsection{Colorado (CO) Study}

This study started in 2006 on a Norka-Colby very fine sandy loam (fine-silty, mixed, mesic Aridic, Argiustolls) with 3-9\% slope near Akron, CO. Tillage treatments were no-till (NT) and the incorporation of nutrient sources with conventional tillage (CT), defined as sweep tillage at about $13 \mathrm{~cm}$ depth. Organic manure amendment (beef manure) was applied yearly at a low (34 $\left.\mathrm{kg} \mathrm{N} \mathrm{ha}^{-1}\right)$ and a high $\left(96 \mathrm{~kg} \mathrm{~N} \mathrm{ha}^{-1}\right)$ rate. The control treatment was represented in plots with no manure addition. For the CT treatment, the manure was surface broadcast in the fall and incorporated within a week after application. For the NT treatment, manure was surface applied immediately prior to planting. At this site the crop rotation was corn (Zea mays L.) in 2006, proso millet (Panicum miliaceum L.) in 2007, and forage winter triticale [a cereal hybrid derived by crossing wheat (Triticum sp.) with cereal rye (Secale sp.)] in 2008. Plot size was $13.7 \mathrm{~m}$ wide and $15.2 \mathrm{~m} \mathrm{long}$, and the average yearly precipitation was $\sim 400 \mathrm{~mm}$. 


\subsection{Kansas (KS) Study}

This study started in 2006 on an Armo silt loam soil (fine-loamy, mixed, mesic, Typic Haplustolls) with $1-3 \%$ slope in Hays, KS. Tillage treatments consisted of NT and the incorporation of nutrient sources with CT using sweep tillage at $13 \mathrm{~cm}$ depth. Beef manure was applied yearly at a low $\left(67 \mathrm{~kg} \mathrm{~N} \mathrm{ha}^{-1}\right)$ and a high $\left(134 \mathrm{~kg} \mathrm{~N} \mathrm{ha}^{-1}\right)$ rate. We also evaluated plots under inorganic fertilizer (urea) applied yearly at the same manure $\mathrm{N}$ rates. The control treatment represented plots that received no manure or fertilizer. For the CT treatments, fertilizer or manure was applied as surface broadcast and then incorporated with the sweep tiller, while for NT treatments were surface applied. The crop rotation used was grain sorghum (Sorghum bicolor L.) in 2006, forage oat (Avena sativa L.) in spring of 2007, winter wheat (Triticum aestivum L.) in fall of 2007, and fallow in 2008. Plot size was $6.0 \mathrm{~m}$ wide and $13.5 \mathrm{~m}$ long, and average precipitation was $\sim 649 \mathrm{~mm}$.

\subsection{Kentucky (KY) Study}

This study started in 2004 on a Crider silt loam soil (fine-silty, mixed, active, mesic, Typic Paleudalf) with 2-6\% slope in Bowling Green, KY. For the CT treatments, manure was applied as surface broadcast and then incorporated with a rotary tiller, while for NT, treatments were surface applied. Manure treatments consisted of a control, which received no chemical fertilizer or manure, and two types of manure (poultry and dairy) applied at a rate of $403 \mathrm{~kg} \mathrm{~N} \mathrm{ha}^{-1}$. The plots were under continuous corn planted in $3.05 \mathrm{~m} \times 6.1 \mathrm{~m}$ plots in early May and harvested as grain in September. Monthly rainfall precipitation during the course of the study was on average 140,101, 120, 106, and $114 \mathrm{~mm}$ in 2004, 2005, 2006, 2007, and 2008, respectively. More information on this study, including corn grain yields and other soil properties are given by Sistani et al. [12].

\subsection{Soil Sampling}

Sites were sampled between March and April in each year and samples were obtained from the three field replicates of each treatment. A composite soil sample consisting of ten $2.5 \mathrm{~cm}$ diameter cores was taken from the $0-5$ and $5-10 \mathrm{~cm}$ depths of each treatment using an Oakfield soil probe (Forestry Supplies, Inc. Jackson, MS). Samples were collected between the rows from each plot and wheel-traffic areas were purposely avoided. Soil samples were placed in sterile polypropylene bags kept in coolers during field sampling and stored at $4{ }^{\circ} \mathrm{C}$ after collection.

\subsection{Soil and Manure Analyses}

Soil $(<5 \mathrm{~mm})$ and manure $\mathrm{pH}$ were evaluated in air-dried samples using a glass electrode with a 1:1 soil or manure:water ratio. Soil was analyzed for organic $\mathrm{C}$ and total $\mathrm{N}$ whereas manure was analyzed for total $\mathrm{C}$ and $\mathrm{N}$ contents by using a Vario Max CN analyzer (Elementar Americas, Inc., Mt. Laurel, NJ, USA). Total P was analyzed in the manure using the Mehlich-3 (M3) extractant [13]. The general properties of the manure used in these studies are provided in Table 1. 
Table 1. Selected properties of the manure applied to the field studies.

\begin{tabular}{|c|c|c|c|c|c|c|c|c|c|}
\hline \multirow[t]{2}{*}{ Field Study } & \multirow[t]{2}{*}{ Manure } & \multicolumn{2}{|c|}{ Application } & \multirow[t]{2}{*}{ Crop } & \multirow{2}{*}{$\begin{array}{c}\text { Moisture } \\
\%\end{array}$} & TC & \multirow{2}{*}{\multicolumn{2}{|c|}{$\begin{array}{l}\text { TN TP } \\
\left(\mathrm{g} \mathrm{kg}^{-1}\right)\end{array}$}} & \multirow[t]{2}{*}{ pH } \\
\hline & & Year & Season & & & & & & \\
\hline \multirow[t]{2}{*}{ Colorado } & Beef & 2006 & Fall & Corn & 30.3 & 367.6 & 32.9 & 4.8 & 6.2 \\
\hline & & 2007 & Fall & Proso Millet & 39.8 & 364.5 & 13.6 & 5.0 & 8.1 \\
\hline \multirow[t]{4}{*}{ Kansas } & Beef & 2006 & Spring & Forage sorghum & 37.0 & 491.0 & 22.0 & 3.8 & 5.0 \\
\hline & & 2007 & Spring & Oat & 43.0 & 288.8 & 7.7 & 1.8 & 4.5 \\
\hline & & & Fall & Winter wheat & 8.5 & 144.8 & 10.2 & 2.6 & 8.0 \\
\hline & & 2008 & & Fallow & & & & & \\
\hline \multirow[t]{8}{*}{ Kentucky } & Poultry & 2004 & Fall & Corn & 42.0 & 200.0 & 25.0 & 25 & 6.9 \\
\hline & & 2005 & & & 32.0 & 225.5 & 27.7 & 24 & 7.1 \\
\hline & & 2006 & & & 32.0 & 245.9 & 29.5 & 23 & 6.7 \\
\hline & & 2007 & & & 32.0 & 265.1 & 29.8 & 25 & 6.2 \\
\hline & Dairy & 2004 & Fall & Corn & 78.0 & 105.0 & 6.0 & 12 & 8.5 \\
\hline & & 2005 & & & 79.0 & 95.1 & 6.2 & 12 & 8.3 \\
\hline & & 2006 & & & 78.0 & 88.8 & 8.0 & 14 & 6.9 \\
\hline & & 2007 & & & 58.0 & 196.1 & 10.1 & 11 & 7.7 \\
\hline
\end{tabular}

Microbial biomass C (MBC) was determined in field-moist soil (15-g oven-dry equivalent) by the chloroform-fumigation-extraction method [14] using a kEC factor of 0.45 [15]. The organic $\mathrm{C}$ from the fumigated $(24 \mathrm{~h})$ and non-fumigated (control) soil was quantified using a $\mathrm{CN}$ analyzer (Shimadzu Model TOC-V/CPH-TN, Shimadzu Corporation, Japan).

Enzyme activities were determined in soil based on assays described in Tabatabai [16] for determination of the activities of $\beta$-glucosidase, $\alpha$-galactosidase, and phosphomonoesterases; whereas, $\beta$-glucosaminidase activity was determined as described in Parham and Deng [7]. The enzyme activities were assayed ( $<5 \mathrm{~mm}$ air-dried soil) in duplicates at their optimal $\mathrm{pH}$ values and appropriate substrate (all are p-nitrophenol derivates releasing p-nitrophenol or PN). The controls were soil samples to which substrate was added after the incubation step.

\subsection{Statistical Analyses}

Analysis of Variance (ANOVA) was conducted to examine the effects of tillage, manure type or manure application rate (the manure treatment varied among sites) and their interaction on the enzyme activity. Generally, the tillage practices were not significant. Enzyme activity for every year and soil depth was evaluated using the $\mathrm{R}$ statistical software [17] with the Vegan package for Principal Component Analysis (PCA) [18]. We evaluated the enzyme activities by both PCA and model-based redundancy analysis (RDA) [19,20], and both provided similar results. Therefore, results for the enzyme activities were presented in PCA plots. PCA plots of the correlation matrix were obtained for each year and depth, with a $95 \%$ confidence for the enzyme activity, to determine separation due to manure treatment regardless of tillage. 


\section{Results}

Results showed that tillage treatment had no significant effects on enzyme activities within the first years of manure applications. Thus, for each soil at the three sites (CO, KS and KY), the value of the enzyme activities reported is an average of both tillage and no-tillage practices.

\subsection{Soil Enzyme Activities as a Function of Beef Manure Application Rates in CO}

For the $0-5 \mathrm{~cm}$ soil depth, PCA plots including 5 enzyme activities indicated separation of the high application rate from the control and low application rate after the first year of beef manure application (Figure 1). The PCA plot for the second year of beef manure applications showed a trend of separation between the control and low manure application treatment, which is more obvious when comparing the PCA plots of the first and second year.

Figure 1. Enzyme activities as affected by beef manure applications for the $0-5 \mathrm{~cm}$ depth in a fine sandy loam in Colorado $(\mathrm{CO}) \quad(\beta$-Gluc $=\beta$-Glucosidase; Acid $\mathrm{Ph}=$ Acid Phosphatase; Alk $\mathrm{Ph}=$ Alkaline phosphatase; $\alpha$-Gal $=\alpha$-Galactosidase; $\beta$-Glsm $=\beta$-Glucosaminidase) .
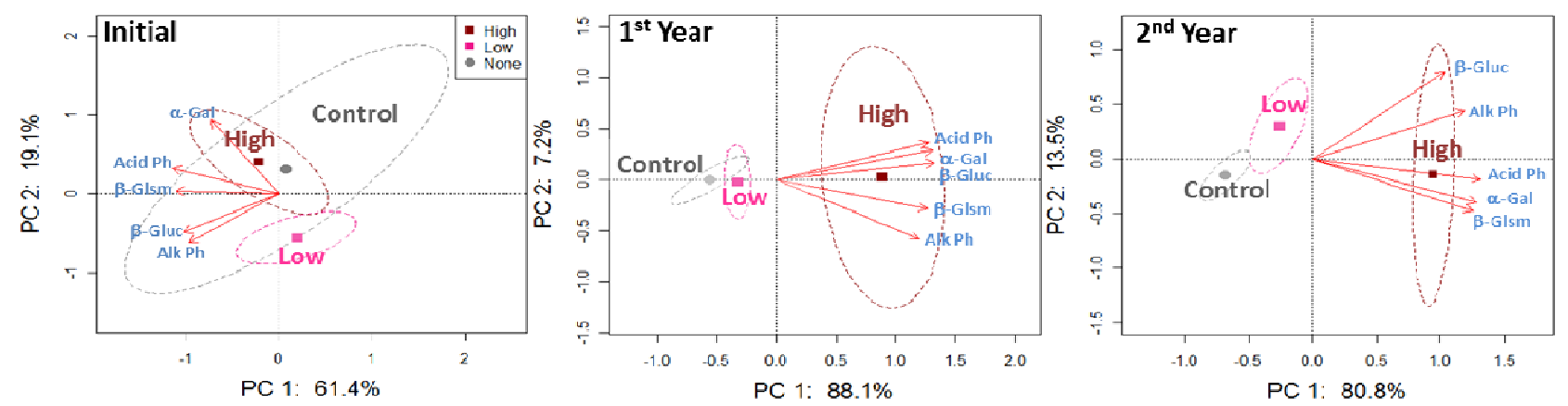

Individual evaluation of each enzyme activity after the first year of the beef manure application indicated that $\beta$-glucosaminidase and $\alpha$-galactosidase activities were the most responsive enzymes to the high application rate, which were about 3 times greater than the control (Table 2). After 2 years, only acid phosphatase activity was different among the three manure application rates (control $<$ low $<$ high), while the other enzyme activities were not different in the low application rate and the control.

The PCA plots for 5-10 cm soil depth did not show separation due to the beef manure application rates until the second year of the study, when all enzyme activities grouped near the high manure application rate along PC1 (Figure 2). The enzyme activities were generally between 20-58\% greater in the high application rate than the control by the second year of the study at this lower soil depth (Table 2). 
Figure 2. Enzyme activities as affected by second year of manure applications at the 5-10 cm depth in $\mathrm{CO}$ ( $\beta$-Gluc $=\beta$-Glucosidase; Acid $\mathrm{Ph}=$ Acid Phosphatase; $\mathrm{Alk} \mathrm{Ph}=$ Alkaline phosphatase; $\alpha$-Gal $=\alpha$-Galactosidase; $\beta$-Glsm $=\beta$-Glucosaminidase).

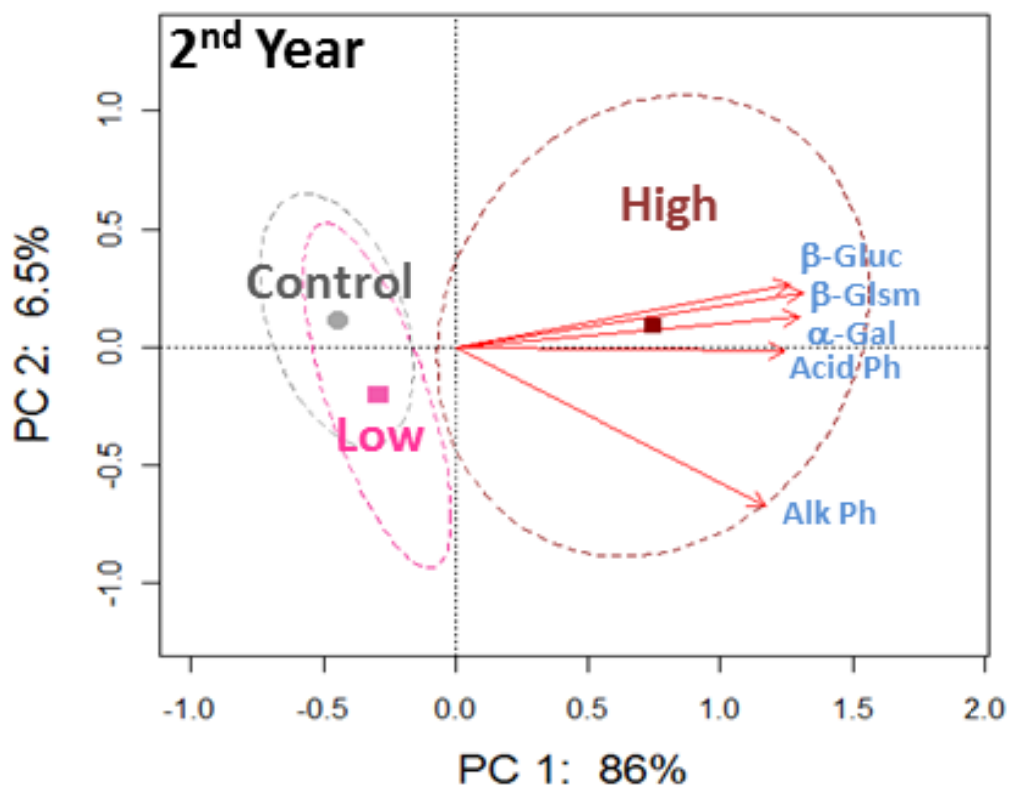

Table 2. Enzyme activities in a fine sandy loam as a function of beef manure application rates in $\mathrm{CO}^{\dagger}$.

\begin{tabular}{|c|c|c|c|c|c|c|c|}
\hline \multirow{2}{*}{$\begin{array}{l}\text { Enzyme Activities } \\
\left(\mathrm{mg} \mathrm{PN} \mathrm{kg}^{-1} \text { soil h}^{-1}\right)\end{array}$} & \multirow[b]{2}{*}{ Year } & \multicolumn{3}{|c|}{$0-5 \mathrm{~cm}$} & \multicolumn{3}{|c|}{$5-10 \mathrm{~cm}$} \\
\hline & & Control & Low & High & Control & Low & High \\
\hline \multirow[t]{3}{*}{ Acid Phosphatase } & Initial & $59.98 \mathrm{a}$ & $59.18 \mathrm{a}$ & $65.37 \mathrm{a}$ & $60.66 \mathrm{a}$ & $58.37 \mathrm{a}$ & $64.81 \mathrm{a}$ \\
\hline & 1st year & $62.06 \mathrm{~b}$ & $76.09 \mathrm{~b}$ & $123.31 \mathrm{a}$ & $65.07 \mathrm{a}$ & $66.96 \mathrm{a}$ & $70.17 \mathrm{a}$ \\
\hline & 2nd year & $63.52 \mathrm{c}$ & $81.20 \mathrm{~b}$ & $142.53 \mathrm{a}$ & $49.79 \mathrm{~b}$ & $56.54 \mathrm{~b}$ & $78.38 \mathrm{a}$ \\
\hline \multirow[t]{3}{*}{ Alkaline Phosphatase } & Initial & $196.95 \mathrm{a}$ & $205.91 \mathrm{a}$ & $183.46 \mathrm{a}$ & $174.35 \mathrm{a}$ & $178.95 \mathrm{a}$ & $161.42 \mathrm{a}$ \\
\hline & 1st year & $208.19 \mathrm{~b}$ & $242.98 \mathrm{~b}$ & $357.70 \mathrm{a}$ & $185.91 \mathrm{a}$ & $184.15 \mathrm{a}$ & $169.64 \mathrm{a}$ \\
\hline & 2nd year & $219.50 \mathrm{~b}$ & $268.62 \mathrm{~b}$ & $385.77 \mathrm{a}$ & $159.27 \mathrm{~b}$ & $169.80 \mathrm{ab}$ & $199.80 \mathrm{a}$ \\
\hline \multirow[t]{3}{*}{$\alpha$-Galactosidase } & Initial & $15.25 \mathrm{a}$ & $11.93 \mathrm{a}$ & $15.25 \mathrm{a}$ & $8.17 \mathrm{a}$ & $7.07 \mathrm{a}$ & $8.62 \mathrm{a}$ \\
\hline & 1st year & $11.52 \mathrm{~b}$ & $14.94 \mathrm{~b}$ & $34.34 \mathrm{a}$ & $5.67 \mathrm{a}$ & $5.27 \mathrm{a}$ & $6.53 \mathrm{a}$ \\
\hline & 2nd year & $9.58 \mathrm{~b}$ & $14.00 \mathrm{~b}$ & $36.51 \mathrm{a}$ & $3.19 \mathrm{~b}$ & $3.29 \mathrm{~b}$ & $7.67 \mathrm{a}$ \\
\hline \multirow[t]{3}{*}{$\beta$-Glucosidase } & Initial & $84.88 \mathrm{a}$ & $91.28 \mathrm{a}$ & $92.24 \mathrm{a}$ & $71.03 \mathrm{a}$ & $55.31 \mathrm{a}$ & $66.13 \mathrm{a}$ \\
\hline & 1 st year & $97.28 \mathrm{~b}$ & $107.58 \mathrm{~b}$ & $195.31 \mathrm{a}$ & $61.28 \mathrm{a}$ & $56.80 \mathrm{a}$ & $64.22 \mathrm{a}$ \\
\hline & 2nd year & $88.21 \mathrm{~b}$ & $117.21 \mathrm{ab}$ & $143.38 \mathrm{a}$ & $39.41 \mathrm{~b}$ & $41.38 \mathrm{~b}$ & $68.60 \mathrm{a}$ \\
\hline \multirow[t]{3}{*}{$\beta$-Glucosaminidase } & Initial & $16.83 \mathrm{a}$ & $15.54 \mathrm{a}$ & $18.56 \mathrm{a}$ & $15.18 \mathrm{a}$ & $14.26 \mathrm{a}$ & $16.62 \mathrm{a}$ \\
\hline & 1st year & $14.29 \mathrm{~b}$ & $18.06 \mathrm{~b}$ & $51.95 \mathrm{a}$ & $14.16 \mathrm{a}$ & $13.60 \mathrm{a}$ & $15.07 \mathrm{a}$ \\
\hline & 2nd year & $14.09 \mathrm{~b}$ & $25.26 \mathrm{~b}$ & $77.92 \mathrm{a}$ & $11.59 \mathrm{~b}$ & $12.01 \mathrm{~b}$ & $19.34 \mathrm{a}$ \\
\hline
\end{tabular}

$\dagger$ Different letters for each enzyme activity at the same depth and year indicate significant differences $(P<0.05)$. Values include both tillage treatments $(\mathrm{n}=6)$, which were not significant. 


\subsection{Soil Enzyme Activities as a Function of Beef Manure Application Rates in KS}

The PCA plots for four enzyme activities at $0-5 \mathrm{~cm}$ soil depth revealed no separation of the low and high beef manure application rates from the control after the first year (Figure 3). However, $\alpha$-galactosidase and $\beta$-glucosaminidase activities were more associated with the high application rate, which may explain that the high application rate treatment was already grouping by itself along axis 1 . By the second and third year of beef manure applications, the PCA plots showed that all enzyme activities were associated to both low and high beef manure application rates.

Figure 3. Enzyme activities as affected by the first years of beef manure applications for the $0-5 \mathrm{~cm}$ depth in a silt loam in Kansas (KS).
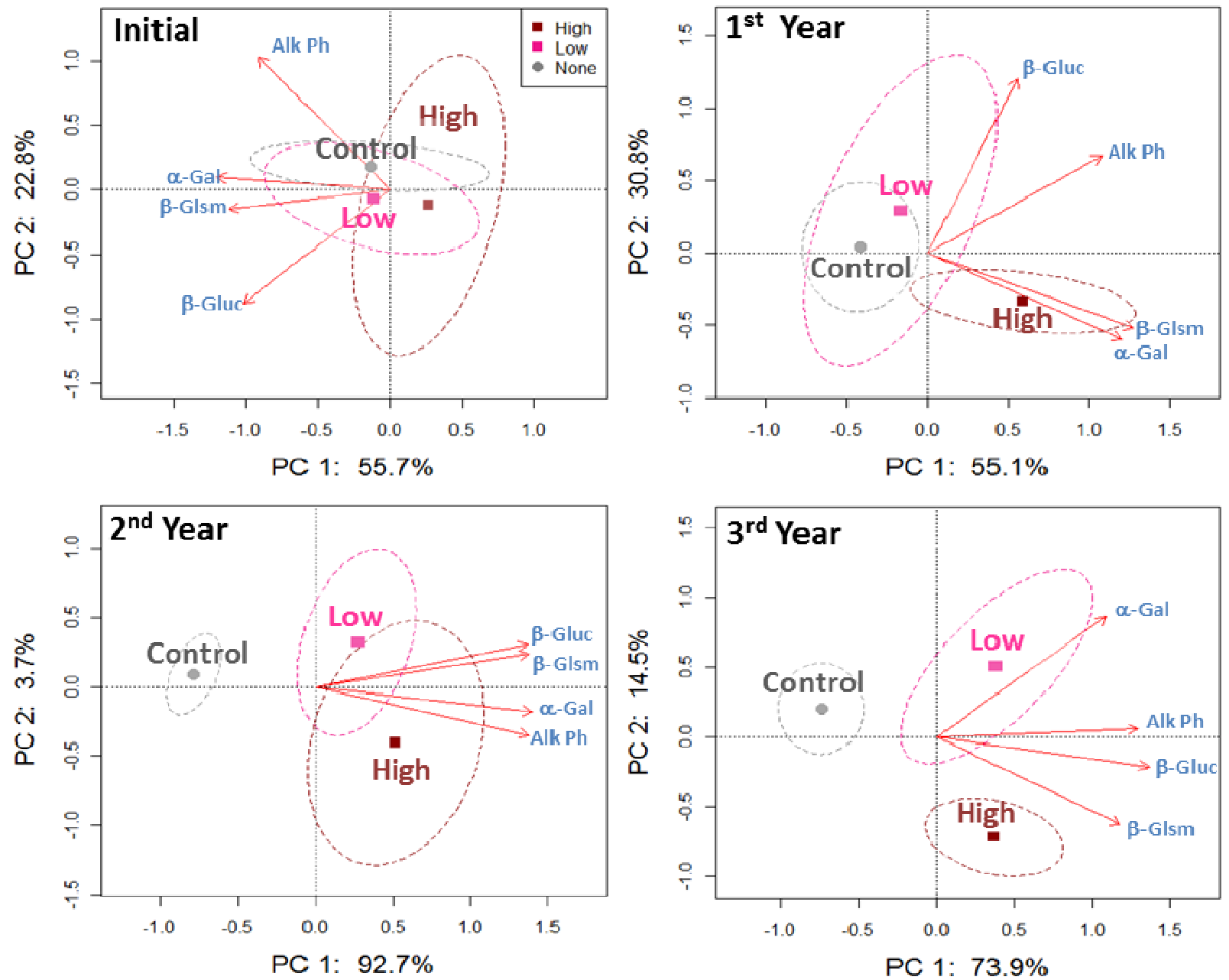

Although all enzyme activities were increased by beef manure by the second year, individual evaluation of the enzyme activity levels showed that $\beta$-glucosaminidase activity was doubled in soil under the low and high application rates compared to the control (Table 3). By the third year of beef manure applications, $\beta$-glucosaminidase and $\alpha$-galactosidase showed 37 to $43 \%$ greater activities in the manure treated soil while alkaline phosphatase activity was only $22 \%$ greater in the beef manure treated soil compared to the control. Although an inorganic fertilized treatment, also evaluated here, was not included in the PCAs, results (Table 3) showed that the soil enzyme activities were similar in the inorganic fertilized plots and the control. 
Table 3. Enzyme activities in a silt loam as a function of beef manure application rates in $\mathrm{KS}{ }^{\dagger}$.

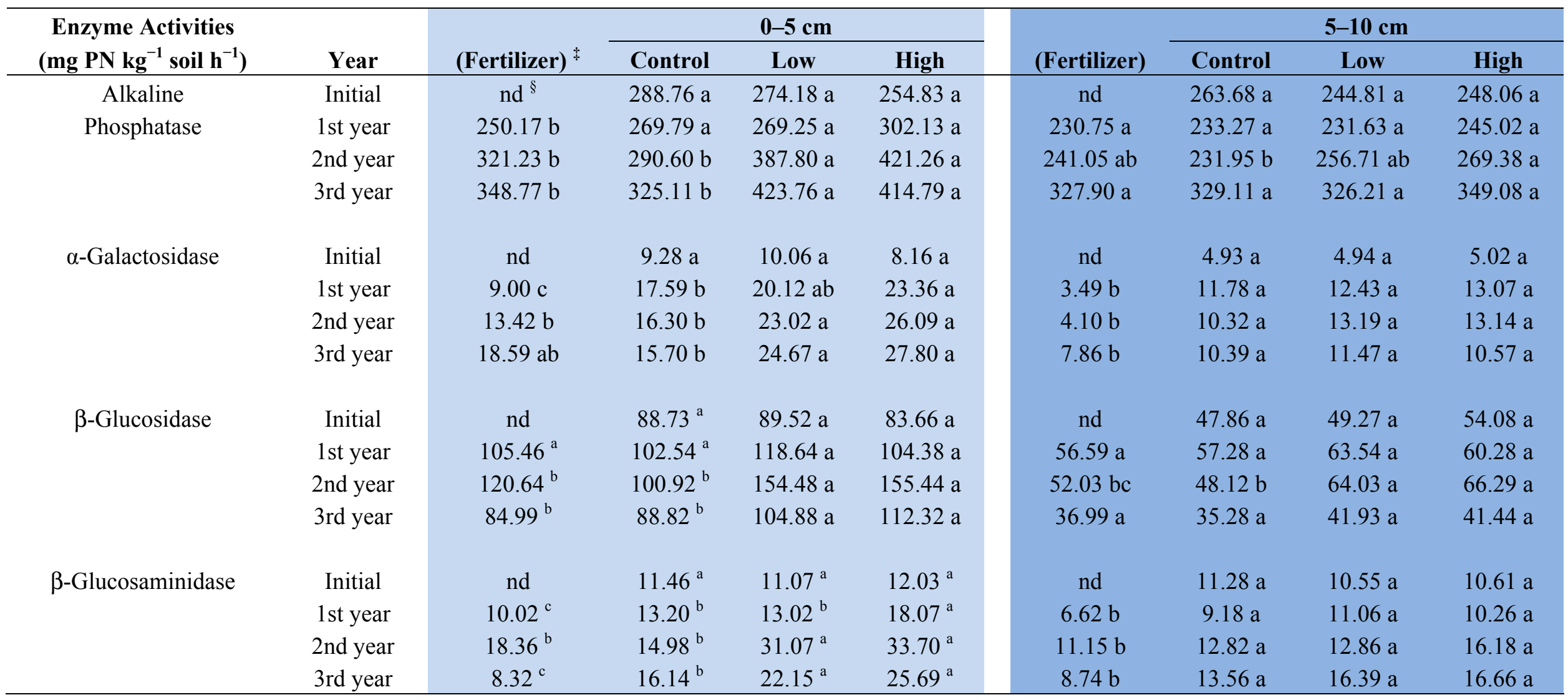

${ }^{\dagger}$ Different letters for each enzyme activity at the same depth and year indicate significant differences $(P<0.05)$. Values include both tillage treatments $(\mathrm{n}=6)$, which were not significant; ${ }^{\ddagger}$ A comparison of the soil enzyme activities in plots under inorganic fertilizer was also established; ${ }^{\S}$ nd $=$ not determined. 
The PCA plots for all enzyme activities at 5-10 $\mathrm{cm}$ did not show separation among the beef manure application rates, except for a trend detected in the second year of applications (Figure 4). Most enzyme activities were not responsive to the beef manure applications at this lower depth, and there were only greater activities of alkaline phosphatase and $\beta$-glucosidase in the high application rate compared to the control in the second year of applications (Table 3 ).

Figure 4. Enzyme activities at the $5-10 \mathrm{~cm}$ as affected by second year of manure applications in $\mathrm{KS}(\beta$-Gluc $=\beta$-Glucosidase; Acid $\mathrm{Ph}=$ Acid Phosphatase; Alk $\mathrm{Ph}=$ Alkaline phosphatase; $\alpha$-Gal $=\alpha$-Galactosidase; $\beta$-Glsm $=\beta$-Glucosaminidase) .

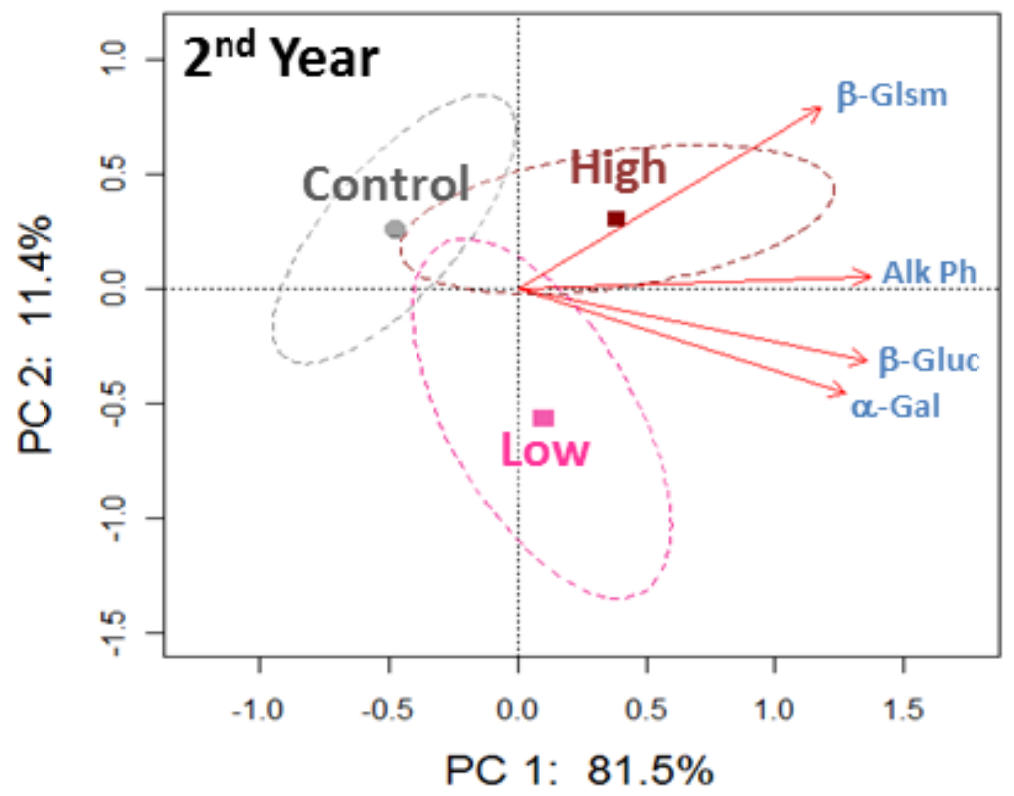

\subsection{Soil Enzyme Activities as a Function of Dairy and Poultry Manure in KY}

The PCA plots for four enzyme activities together at $0-5 \mathrm{~cm}$ soil depth showed separation of both dairy and poultry manure treatments from the control since the first year, and the separation among treatments became more apparent over time (Figure 5). Greater acid phosphatase activity was associated with the poultry treated soil; whereas, $\mathrm{C}$ cycling enzyme activities, i.e., $\beta$-glucosaminidase and $\beta$-glucosidase, were similar in the dairy and poultry treated soil (Table 4 ).

The PCA plots that included together the four enzyme activities at 5-10 $\mathrm{cm}$ soil depth did not show separation due to dairy or poultry manure applications until the second and third year (Figure 6). More significant differences in the enzyme activities among treatments were detected in the third year, but acid phosphatase activity was never affected at this lower soil depth (Table 4). 
Figure 5. Enzyme activities after the first years of poultry or dairy manure applications for the $0-5 \mathrm{~cm}$ depth in a silt loam soil in Kentucky (KY).
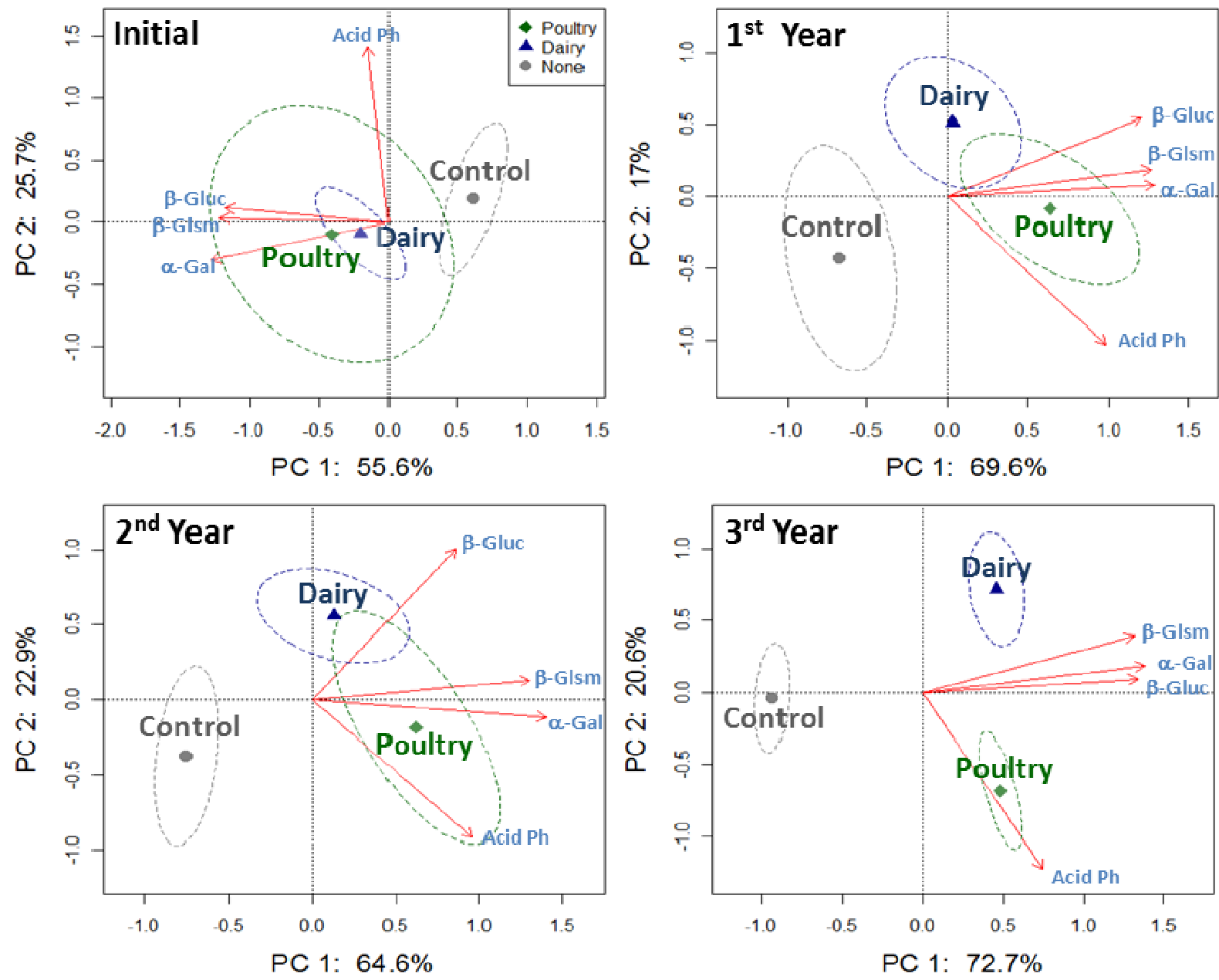

Figure 6. Enzyme activities as affected by poultry or dairy manure applications in a silt loam soil at 5-10 cm depth in KY.
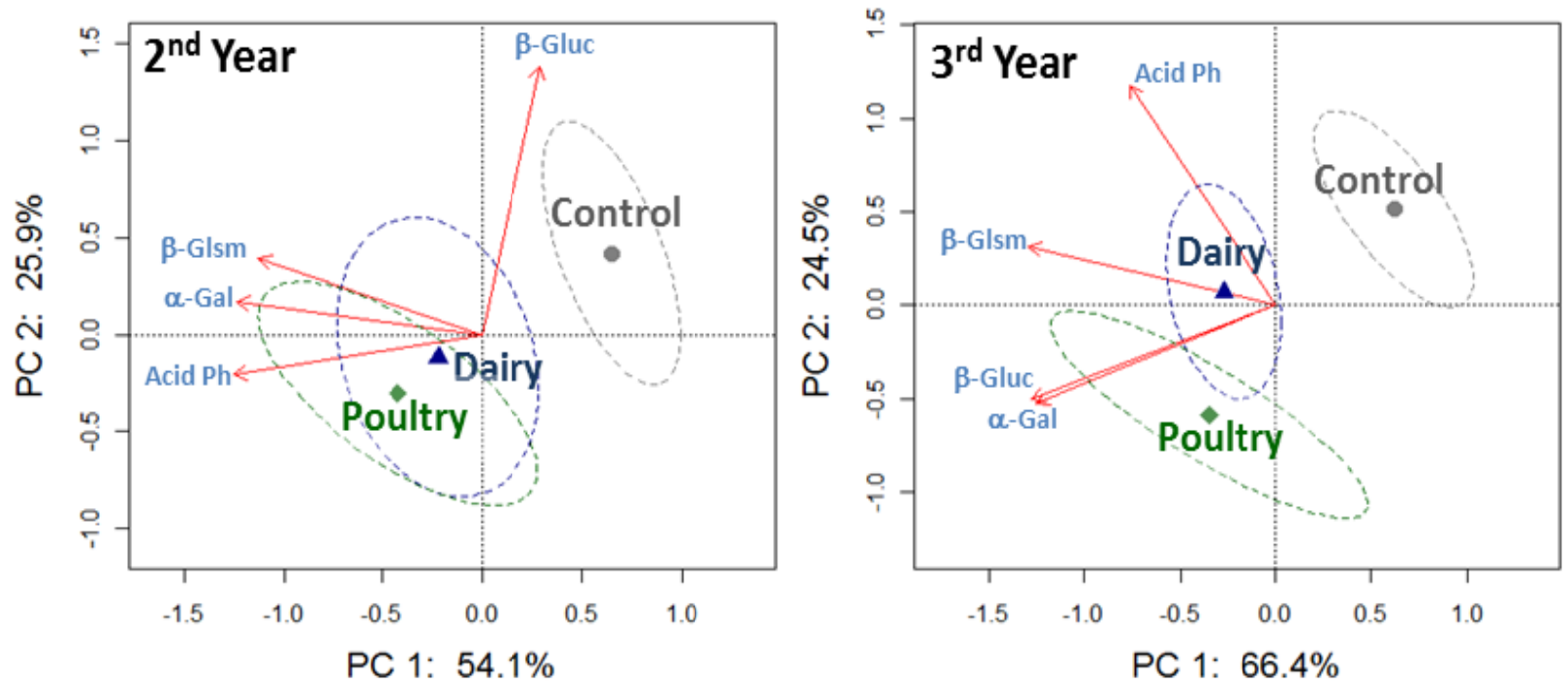
Table 4. Enzyme activities in a silt loam as a function of different manure types in $\mathrm{KY}^{\dagger}$.

\begin{tabular}{|c|c|c|c|c|c|c|c|}
\hline \multirow{2}{*}{$\begin{array}{l}\text { Enzyme Activities } \\
\left(\mathrm{mg} \mathrm{PN} \mathrm{kg}^{-1} \text { soil h}^{-1}\right)\end{array}$} & \multirow[b]{2}{*}{ Year } & \multicolumn{3}{|c|}{$0-5 \mathrm{~cm}$} & \multicolumn{3}{|c|}{$5-10 \mathrm{~cm}$} \\
\hline & & Control & Dairy & Poultry & Control & Dairy & Poultry \\
\hline \multirow[t]{4}{*}{ Acid Phosphatase } & Initial & $321.22 \mathrm{a}$ & $312.67 \mathrm{a}$ & $310.85 \mathrm{a}$ & $\mathrm{nd}^{*}$ & nd & nd \\
\hline & 1st year & $282.11 \mathrm{ab}$ & $277.85 \mathrm{~b}$ & $308.23 \mathrm{a}$ & $179.62 \mathrm{a}$ & $170.13 \mathrm{a}$ & $172.21 \mathrm{a}$ \\
\hline & 2nd year & $341.31 \mathrm{~b}$ & $330.13 \mathrm{~b}$ & $405.46 \mathrm{a}$ & $229.06 \mathrm{a}$ & $210.79 \mathrm{a}$ & $208.28 \mathrm{a}$ \\
\hline & 3rd year & $303.88 \mathrm{~b}$ & $310.11 \mathrm{~b}$ & $392.76 \mathrm{a}$ & $189.83 \mathrm{a}$ & $190.90 \mathrm{a}$ & $182.31 \mathrm{a}$ \\
\hline \multirow[t]{4}{*}{$\alpha$-Galactosidase } & Initial & $13.12 \mathrm{~b}$ & $26.08 \mathrm{a}$ & $27.29 \mathrm{a}$ & nd & nd & nd \\
\hline & 1st year & $23.07 \mathrm{~b}$ & $30.55 \mathrm{~b}$ & $48.29 \mathrm{a}$ & $8.40 \mathrm{~b}$ & $9.69 \mathrm{ab}$ & $12.15 \mathrm{a}$ \\
\hline & 2nd year & $35.97 \mathrm{~b}$ & $56.80 \mathrm{a}$ & $65.45 \mathrm{a}$ & $23.10 \mathrm{~b}$ & $25.70 \mathrm{ab}$ & $28.17 \mathrm{a}$ \\
\hline & 3rd year & $18.01 \mathrm{~b}$ & $43.17 \mathrm{a}$ & $40.18 \mathrm{a}$ & $5.21 \mathrm{c}$ & $8.45 \mathrm{~b}$ & $12.14 \mathrm{a}$ \\
\hline \multirow[t]{4}{*}{$\beta$-Glucosidase } & Initial & $145.22 \mathrm{~b}$ & $158.57 \mathrm{ab}$ & $191.33 \mathrm{a}$ & nd & nd & nd \\
\hline & 1st year & $151.95 \mathrm{~b}$ & $222.14 \mathrm{a}$ & $237.10 \mathrm{a}$ & $72.30 \mathrm{~b}$ & $75.13 \mathrm{~b}$ & $95.66 \mathrm{a}$ \\
\hline & 2nd year & $182.50 \mathrm{~b}$ & $308.14 \mathrm{a}$ & $316.35 \mathrm{a}$ & $78.30 \mathrm{~b}$ & $103.43 \mathrm{a}$ & $113.36 \mathrm{a}$ \\
\hline & 3rd year & $154.43 \mathrm{~b}$ & $272.99 \mathrm{a}$ & $281.01 \mathrm{a}$ & $57.76 \mathrm{~b}$ & $86.87 \mathrm{a}$ & $89.32 \mathrm{a}$ \\
\hline \multirow[t]{4}{*}{$\beta$-Glucosaminidase } & Initial & $33.07 \mathrm{~b}$ & $46.50 \mathrm{a}$ & $45.85 \mathrm{a}$ & nd & nd & nd \\
\hline & 1st year & $44.53 \mathrm{~b}$ & $62.85 \mathrm{a}$ & $66.73 a$ & $24.45 \mathrm{a}$ & $25.55 \mathrm{a}$ & $27.10 \mathrm{a}$ \\
\hline & 2nd year & $41.93 \mathrm{~b}$ & $64.94 \mathrm{a}$ & $67.87 \mathrm{a}$ & $23.94 \mathrm{a}$ & $28.55 \mathrm{a}$ & $25.71 \mathrm{a}$ \\
\hline & 3rd year & $33.41 \mathrm{c}$ & $74.77 \mathrm{a}$ & $61.46 \mathrm{~b}$ & $20.01 \mathrm{~b}$ & $23.97 \mathrm{a}$ & $22.18 \mathrm{ab}$ \\
\hline
\end{tabular}

$\dagger$ Different letters for each enzyme activity at the same depth and year indicate significant differences $(P<0.05)$. Values include both tillage treatments $(\mathrm{n}=6)$, which were not significant;

${ }^{\ddagger} \mathrm{Nd}=$ not determined.

\subsection{Additional Soil Properties in the Three Sites at the End of the Studies}

The studies showed that soil $\mathrm{pH}$ decreased from 6.8 to 6.5 by the poultry manure applications at both soil depths in KY (Table 5). For the CO study, soil microbial biomass C (MBC), soil organic C (SOC) and total $\mathrm{N}(\mathrm{TN})$ were only greater in the high beef manure application rate at $0-5 \mathrm{~cm}$, but there were no differences in these soil properties at 5-10 $\mathrm{cm}$. For the $\mathrm{KS}$ study, MBC and TN were greater under low and high beef manure application rates compared to the control for the $0-5 \mathrm{~cm}$, which is similar to the trends of enzyme activities; whereas, SOC was only significantly different in the high beef manure application rate compared to the control. At 5-10 cm depth in KS, only MBC was greater in the high beef manure application rate compared to the control. In the KY soil, MBC, SOC and TN were greater due to dairy and poultry manure compared to the control at $0-5 \mathrm{~cm}$, which was also found for the $\mathrm{C}$ cycling enzyme activities. 
Table 5. Additional soil properties evaluated in the last year of the field studies corresponding to year 2 in $\mathrm{CO}$ and year 3 in $\mathrm{KS}$ and $\mathrm{KY}^{\dagger}$.

\begin{tabular}{|c|c|c|c|c|c|c|c|c|c|}
\hline \multirow{3}{*}{$\begin{array}{l}\text { Soil } \\
\text { Properties }\end{array}$} & \multicolumn{6}{|c|}{ Beef manure applied at different rates } & \multirow{2}{*}{\multicolumn{3}{|c|}{$\begin{array}{c}\text { Different manure } \\
\text { at same rate } \\
\text { Kentucky study } \\
\text { (silt loam) } \\
\end{array}$}} \\
\hline & \multicolumn{3}{|c|}{$\begin{array}{l}\text { Colorado study } \\
\text { (fine sandy loam) }\end{array}$} & \multicolumn{3}{|c|}{$\begin{array}{c}\text { Kansas study } \\
\text { (silt loam) }\end{array}$} & & & \\
\hline & Control & Low & High & Control & Low & High & Control & Dairy & Poultry \\
\hline & & & & & $-0-5 \mathrm{~cm}^{-}$ & & & & - \\
\hline $\mathrm{MBC}$ & $247.3 \mathrm{~b}$ & $267.2 \mathrm{~b}$ & $376.6 \mathrm{a}$ & $300.9 \mathrm{~b}$ & 429.9 a & $439.2 \mathrm{a}$ & $299.5 \mathrm{~b}$ & $526.0 \mathrm{a}$ & $439.5 \mathrm{a}$ \\
\hline Organic C & $9.5 \mathrm{~b}$ & $11.2 \mathrm{~b}$ & $14.5 \mathrm{a}$ & $14.8 \mathrm{~b}$ & $16.5 \mathrm{ab}$ & $17.7 \mathrm{a}$ & $15.0 \mathrm{c}$ & $27.9 \mathrm{a}$ & $22.3 \mathrm{~b}$ \\
\hline Total N & $1.1 \mathrm{~b}$ & $1.3 \mathrm{~b}$ & $1.7 \mathrm{a}$ & $1.5 \mathrm{~b}$ & $1.6 \mathrm{a}$ & $1.7 \mathrm{a}$ & $1.6 \mathrm{~b}$ & $2.7 \mathrm{a}$ & $2.4 \mathrm{a}$ \\
\hline Soil pH & $7.9 \mathrm{a}$ & $8.0 \mathrm{a}$ & $7.8 \mathrm{a}$ & $8.3 \mathrm{a}$ & $8.3 \mathrm{a}$ & $8.1 \mathrm{a}$ & $6.8 \mathrm{a}$ & $6.8 \mathrm{a}$ & $6.5 \mathrm{~b}$ \\
\hline & & & & & $5-10 \mathrm{~cm}$ & & & & - \\
\hline $\mathrm{MBC}$ & $168.3 \mathrm{a}$ & $177.0 \mathrm{a}$ & $202.3 \mathrm{a}$ & $240.7 \mathrm{~b}$ & $260.5 \mathrm{a} \mathrm{b}$ & $282.3 \mathrm{a}$ & $141.9 \mathrm{a}$ & $160.1 \mathrm{a}$ & $166.9 \mathrm{a}$ \\
\hline Organic C & $8.7 \mathrm{a}$ & $8.7 \mathrm{a}$ & $9.5 \mathrm{a}$ & $13.6 \mathrm{a}$ & $13.3 \mathrm{a}$ & $14.5 \mathrm{a}$ & $9.6 \mathrm{~b}$ & $11.6 \mathrm{a}$ & $11.3 \mathrm{a}$ \\
\hline Total N & $1.1 \mathrm{a}$ & $1.1 \mathrm{a}$ & $1.2 \mathrm{a}$ & $1.4 \mathrm{a}$ & $1.4 \mathrm{a}$ & $1.4 \mathrm{a}$ & $1.2 \mathrm{~b}$ & $1.3 \mathrm{a}$ & $1.3 \mathrm{a}$ \\
\hline Soil pH & $8.1 \mathrm{a}$ & $8.0 \mathrm{a}$ & $7.7 \mathrm{a}$ & $8.5 \mathrm{a}$ & $8.4 \mathrm{a}$ & $8.3 \mathrm{a}$ & $6.8 \mathrm{ab}$ & $6.9 \mathrm{a}$ & $6.6 \mathrm{~b}$ \\
\hline
\end{tabular}

$\dagger$ Within the same field study, different letters for each property at the same depth indicate significant differences $(P<0.05)$. Means reported includes both tillage treatments $(\mathrm{n}=6)$, which were not significant;

${ }^{*}$ The units for the soil properties are: $\mathrm{MBC}=\mathrm{mg} \mathrm{C} \mathrm{kg}^{-1}$ soil; Organic $\mathrm{C}=\mathrm{g} \mathrm{C} \mathrm{kg}^{-1}$ soil; Total $\mathrm{N}=\mathrm{g} \mathrm{N} \mathrm{kg}^{-1} \mathrm{soil}$.

\section{Discussion}

\subsection{Soil Enzyme Activities as a Function of Beef Manure Application Rates in CO and KS}

Significant increases in soil microbial communities and their enzyme activities can be expected under long-term manure applications [21-23]; however, the early assessment conducted with $\mathrm{CO}$ and KS studies revealed different responses of the soil enzyme activities depending on the climatic conditions and soil type. For example, there was a faster increase in all soil enzyme activities under the high rate of application in $\mathrm{CO}$ possibly related to the sandy nature of the soil (fine sandy loam) with lower SOM and clay contents compared to the silt loam soil in KS, which did not show the separation of all enzyme activities until the second year. In addition to differences in SOM levels in the KS and $\mathrm{CO}$ soils, there could also be differences in SOM quality, indicating a different microbial community and production of enzymes within the first year in the sandier soil in CO compared to the KS soil. Although all enzyme activities responded faster in the sandier soil in CO, individual evaluation of each enzyme revealed that for the KS soil, two of four enzyme activities ( $\alpha$-galactosidase and $\beta$-glucosaminidase) were greater in the high beef manure application rate compared to the control after the first year. In this sense, both $\mathrm{CO}$ and $\mathrm{KS}$ studies showed that $\mathrm{C}$ cycling enzyme activities were more responsive to beef manure than the $\mathrm{P}$ cycling enzyme activities evaluated (phosphomonoesterases) after the first year. This finding reflects that high $\mathrm{C}$ levels are provided in beef manure and influence $\mathrm{C}$ cycling enzyme activities regardless of the study and soil type (compared to the poultry and dairy manure used in the KY study). 


\subsection{Soil Enzyme Activities as a Function of Manure Types in KY}

Evaluation of the effects of different manure types on enzyme activities in the KY silt loam soil showed increases in specific soil enzyme activities by certain manure types. The fact that acid phosphatase activity was more associated with soil under poultry manure than with dairy manure could be related to the lower $\mathrm{pH}$ in poultry $(\mathrm{pH}<7) v s$. dairy $(\mathrm{pH}>7)$ manure. The low $\mathrm{pH}$ in added poultry manure caused a decrease in soil $\mathrm{pH}$ and subsequently an increase in acid phosphatase activity. Increases in acid phosphatase activity are generally observed with decreases in soil $\mathrm{pH}$, within a given range [24]. Parham et al. [21] explained that the observed effect of soil $\mathrm{pH}$ on acid phosphatase activity could be due to modifications in the quantity, specific activity, or stability of the enzymes with changes in soil $\mathrm{pH}$. In addition to soil $\mathrm{pH}$, previous studies have emphasized the high levels of $\mathrm{P}$ incorporated by poultry manure increasing the mobility of manure-P in soil with time due to significant increases in P cycling enzyme activities and microbial diversity [21,25]. Therefore, the fast increase in acid phosphatase activity in this soil with poultry manure may indicate improvements to $\mathrm{P}$ cycling. In addition, previous results from the same study (KY) indicated that poultry manure applied as a primary fertilizer at the rate of $13.5 \mathrm{Mg} \mathrm{ha}^{-1}$ during four years did not result in residual soil test $\mathrm{P}, \mathrm{Cu}$ and $\mathrm{Zn}$ levels considered to be harmful to surface water or cropping systems. However, corn grain yields were still similar to those yields from inorganic fertilization under both no-till and tilled conditions [12].

Greater acid phosphatase activity was found in poultry manure than in dairy manure treated soil whereas $C$ cycling enzyme activities involved in chitin ( $\beta$-glucosaminidase), cellulose ( $\beta$-glucosidase) and melibiose ( $\alpha$-galactosidase) degradation were similar in soil treated with dairy manure and the soil under poultry manure. Since total $\mathrm{C}$ content was greater in poultry manure (200-265 $\left.\mathrm{g} \mathrm{kg}^{-1}\right)$ than dairy manure (88-196 $\mathrm{g} \mathrm{kg}^{-1}$ ), it could have been expected to detect greater $\mathrm{C}$ enzyme activities in soil under poultry manure, but this was not the case. Therefore, the $\mathrm{C}$ cycling enzyme activities may have responded to differences in substrates $\mathrm{C}$ quality than in $\mathrm{C}$ quantity between poultry and dairy manure. A recent study by Tejada et al. [26] with new types of organic amendments (i.e., biostimulants) emphasized the effect of substrate C-quality differences in their impact on soil enzyme activities and community structure. They reported that the soil enzyme activities were increased to greater extent by biostimulants with greater amounts of protein and percentage of peptides [26]. In our study, MBC was numerically greater $(17 \%)$ in the surface soil $(0-5 \mathrm{~cm})$ under dairy rather than in the poultry manure treated soil, which may suggest that dairy manure contained more simple $\mathrm{C}$ sources and/or a different (perhaps greater) microbial community. The $\mathrm{C}$ cycling enzymes may have also responded to the fact that dairy manure tended to have higher $\mathrm{pH}$ and greater water (up to 2 fold) than poultry manure. In addition, Sistani et al. [12] reported lower $\mathrm{Cu}$ and $\mathrm{Zn}$ contents in the dairy manure (by half) than in poultry manure used in this study. The $\mathrm{Cu}$ and $\mathrm{Zn}$ are metals that are known to have inhibitory effects on these $\mathrm{C}$ cycling enzymes [27] and thus, may have caused some reductions in these enzyme activities of poultry manure treated soil. Overall, manure properties, regardless of $\mathrm{C}$ content, could explain the similar levels of $\mathrm{C}$ cycling enzyme activities in the dairy manure and the poultry manure treated soils. 


\subsection{Relationship between Changes in Soil Enzyme Activities and Other Soil Properties}

Results from the KS study demonstrate more benefits to biogeochemical cycling with organic amendments compared to inorganic fertilizers as the soil enzyme activities were similar in the inorganic fertilizer and control plots within these first years of plot establishment. In addition, the three studies regardless of soil and manure type, showed the same trend for soil microbial biomass $\mathrm{C}$ and the $\mathrm{C}$ cycling enzyme activities suggesting these enzymes had significant origin from active microbial communities in the manure and/or those increased in soil due to the additional readily available substrates associated to the manure [28,29]. These findings show that organic fertilizers, such as manure, not only provide additional enzymes, microbes and nutrients that are not provided with inorganic fertilizers, but also a better environment to support further increases in soil microbial communities and stabilize soil enzymes, such as the reductions in soil compaction [30,31] and improved SOM and porosity [32].

Our samplings every year between March and April showed generally similar levels of enzyme activities under the same treatment as reported for another study in TX with organic amendments (i.e., poultry manure) [5], however, the levels of the enzyme activities can vary when soils treated with manure are sampled at different times [21]. The use of PCA plots to visualize the response of several enzyme activities in this study was a valuable tool that revealed a gradual progressive separation of the manure treated soils from the control soil over time, which was not possible to be observed from the individual evaluation of each enzyme activity level.

Previous long-term studies in other loam soils have reported that the impact of manure applications on enzyme activities and microbial biomass are detected in the $0-30 \mathrm{~cm}$ soil layer [21]. Similar to our study with enzyme activities, less marked effects of manure applications were detected by a long-term study (12 yrs) on the microbial diversity with depth [33]. However, information on how long does it take for soil enzyme activities to be affected with the applications of organic amendments is scarce. Results from our field studies indicated that the enzyme activity responses were not detected until the second year of manure applications at lower soil depths $(5-10 \mathrm{~cm})$ regardless of manure type and rate, tillage practice, and soil type. However, enzyme activities showed a faster response to manure applications at this lower depth compared to SOC content, which was still not affected due to beef manure in $\mathrm{CO}$ and KS studies. The less marked effects of manure applications on the enzyme activities with depth are explained by the decrease in SOM, nutrients and microbial community composition and activity with soil depth, which can reduce manure decomposition and substrates incorporation into nutrient cycling within the first years of applications.

\section{Conclusions}

This multi-location research showed that the sandier soil (fine sandy loam) responded faster to the beef manure application in $\mathrm{CO}$ rather than the silt loam soil evaluated in KS. Both studies in $\mathrm{CO}$ and $\mathrm{KS}$ showed that $\mathrm{C}$ cycling enzyme activities were more responsive than phosphatase activity to beef manure, which could be in response to the high levels of total $\mathrm{C}$ in beef manure, compared to the poultry and dairy manure used in KY. Also, results from the silt loam under different manure types in $\mathrm{KY}$ revealed that certain enzyme activities might be more predominant under certain types of manure 
and thus, impacting different biochemical reactions of nutrient cycling. The poultry manure had higher $\mathrm{P}$ and $\mathrm{C}$ content than the dairy manure; however, acid phosphatase activity was increased with soil treated with poultry manure whereas $\mathrm{C}$ cycling enzyme activities were similar under both the dairy manure and poultry manure treated soil. This study revealed significant responses in $\mathrm{C}$ and $\mathrm{P}$ cycling enzyme activities to manure applications within 1-2 years at a depth to $10 \mathrm{~cm}$, representing potential benefits in soil biogeochemical cycling, considered essential for the sustainability of agroecosystems supported with organic fertilizers.

\section{Acknowledgments}

We would like to thank Jon Cotton for his technical assistance with the enzyme assays.

\section{Conflict of Interest}

USDA Disclaimer: Mention of trade names or commercial products in this publication is solely for the purpose of providing specific information and does not imply recommendation or endorsement by the U.S. Department of Agriculture. USDA is an equal opportunity provider and employer.

\section{References}

1. Angers, D.A.; N'dayegamyie, A.; Cote, D. Tillage induced differences in organic matter of particle size fractions and microbial biomass. Soil Sci. Soc. Am. J. 1993, 57, 512-516.

2. Lal, R. Global soil erosion by water and carbon dynamics. In Soils and Global Change; Lal, R., Kimble, J.M., Levine, E., Stewart, B.A., Eds.; CRC Press: Boca Raton, FL, USA, 1995; pp. 131-142.

3. Rochette, P.; Gregorich, E.G. Dynamics of soil microbial biomass C, soluble organic C, and $\mathrm{CO}_{2}$ evolution after three years of manure application. Can. J. Soil Sci. 1998, 78, 283-290.

4. Mikha, M.M.; Rice, C.W. Tillage and manure effects on soil and aggregate-associated carbon and nitrogen. Soil Sci. Soc. Am. J. 2004, 68, 809-816.

5. Acosta-Martinez, V.; Harmel, D.R. Soil microbial communities and enzyme activities under various poultry litter application Rates. J. Environ. Qual. 2006, 35, 1309-1318.

6. Kandeler, E.; Kampichler, C.; Horak, O. Influence of heavy metals on the functional diversity of soil microbial communities. Biol. Fertil. Soils 1996, 23, 299-306.

7. Parham, J.A.; Deng, S.P. Detection, quantification and characterization of $\beta$-glucosaminidase activity in soil. Soil Biol. Biochem. 2000, 32, 1183-1190.

8. Ekenler, M.; Tabatabai, M.A. $\beta$-Glucosaminidase activity of soils: Effect of cropping systems and its relationship to nitrogen mineralization. Biol. Fertil. Soils 2002, 36, 367-376.

9. Ekenler, M.; Tabatabai, M.A. $\beta$-glucosaminidase activity as an index of nitrogen mineralization in soils. Commun. Soil Sci. Plant Anal. 2004, 35, 1081-1094.

10. Acosta-Martínez, V.; Upchurch, D.R.; Schubert, A.M.; Porter, D.; Wheeler, T. Early impacts of cotton and peanut cropping systems on selected soil chemical, physical, microbiological and biochemical properties. Biol. Fertil. Soils 2004, 40, 44-54.

11. Eivazi, F.; Tabatabai, M.A. Phosphatases in soils. Soil Biol. Biochem. 1977, 9, 167-172. 
12. Sistani, K.R.; Maysoon, M.M.; Warren, J.G.; Gilfillen, B.; Acosta-Martinez, V.; Willian, T. Nutrient source and tillage impact on corn grain yield and soil properties. Soil Sci. 2010, 175, 593-600.

13. Mehlich, A. Mehlich 3 soil test extractant. Commun. Soil Sci. Plant Anal. 1984, 15, 1409-1416.

14. Brookes, P.C.; Landman, A.; Pruden, G.; Jenkinson, D.S. Chloroform fumigation and the release of soil nitrogen: A rapid direct extraction method to measure microbial biomass nitrogen in soil. Soil Biol. Biochem. 1985, 17, 837-842.

15. Wu, J.; Joergensen, R.G.; Pommerening, B.; Chaussod, R.; Brookes, P.C. Measurement of soil microbial biomass $\mathrm{C}$ by fumigation extraction: An automated procedure. Soil Biol. Biochem. 1990, 22, 1167-1169.

16. Tabatabai, M.A. Soil enzymes. In Methods of Soil Analysis, Part 2: Microbiological and Biochemical Properties. Soil Science Society of America Book Series 5; Mickelson, S.H., Bigham, J.M., Eds.; Soil Science Society of America: Madison, WI, USA, 1994; pp. 775-833.

17. R Development Core Team. $R$ : A Language and Environment for Statistical Computing. $R$ Foundation for Statistical Computing, version 2.13.1; R Foundation for Statistical Computing: Vienna, Austria, 2011. Available online: http://www.R-project.org/ (accessed on 20 February 2011).

18. Oksanen, J.F.; Blanchet, G.; Kindt, R.; Legendre, P.; O’Hara, R.B.; Simpson, G.L.; Solymos, P.; Henry, M.; Stevens, H.; Wagner, H. Vegan: Community Ecology Package, R package version 1; R Foundation for Statistical Computing: Vienna, Austria, 2011; pp. 17-18. Available online: http://CRAN.R-project.org/package=vegan (accessed on 20 February 2011).

19. Legendre, P.; Anderson, M.J. Distance-based redundancy analysis: Testing multispecies responses in multifactoral ecological experiments. Ecol. Monogr. 1999, 69, 1-24.

20. Legendre, P.; Gallagher, E.D. Ecologically meaningful transformations for ordination of species data. Oecologia 2001, 129, 271-280.

21. Parham, J.A.; Deng, S.P.; Raun, W.R.; Johnson, G.V. Long term cattle manure application in soil. I. Effect on soil phosphorus levels, microbial biomass $\mathrm{C}$, and dehydrogenase and phosphatase activities. Biol. Fertil. Soils 2002, 35, 328-337.

22. Larkin, R.P.; Honeycutt, C.W.; Griffin, T.S. Effect of swine and dairy manure amendments on microbial communities in three soils as influenced by environmental conditions. Biol. Fertil. Soils 2005, 42, 1-11.

23. Pérez-Piqueres, A.; Edel-Hermann, V.; Alabouvette, C.; Steinberg, C. Response of soil microbial communities to compost amendments. Soil Biol. Biochem. 2006, 38, 460-470.

24. Acosta-Martinez, V.; Tabatabai, M.A. Enzyme activities in a limed agricultural soil. Biol. Fertil. Soils 2001, 31, 85-91.

25. Parham, J.A.; Deng, S.P.; Da, H.N.; Sun, H.Y.; Raun, W.R. Long-term cattle manure application in soil. II. Effect on soil microbial populations and community structure. Biol. Fertil. Soils 2003, 38, 209-215.

26. Tejada, M.; Benitez, C.; Gomez, I.; Parrado, J. Use of biostimulants on soil restoration: Effects on soil biochemical properties and microbial community. Appl. Soil Ecol. 2011, 49, 11-17.

27. Eivazi, F.; Tabatabai, M.A. Factors affecting glucosidase and galactosidase activities in soils. Soil Biol. Biochem. 1990, 22, 891-897. 
28. García-Gil, J.C.; Plaza, C.; Soler-Rovira, P.; Polo, A. Long-term effects of municipal solid waste compost application on soil enzyme activities and microbial biomass. Soil Biol. Biochem. 2000, 32, 1907-1913.

29. Peacock, A.D.; Mullen, M.D.; Ringelberg, D.B.; Tyler, D.D.; Hedrick, D.B.; Gale, P.M.; White, D.C. Soil microbial responses to dairy manure or ammonium nitrate applications. Soil Biol. Biochem. 2001, 33, 1011-1019.

30. Miller, J.J.; Sweetland, N.J.; Chang, C. Hydrological properties of a clay loam soil after long term cattle manure application. J. Environ. Qual. 2002, 31, 989-996.

31. McVay, K.A.; Budde, J.A.; Fabrizzi, K.; Mikha, M.M.; Rice, C.W.; Schlegel, A.J.; Peterson, D.E.; Sweeney, D.W.; Thompson, C. Management effects on soil physical properties in long-term tillage studies in Kansas. Soil Sci. Soc. Am. J. 2006, 70, 434-438.

32. Pagliai, M.; Vignozzi, N.; Pellegrini, S. Soil structure and the effect of management practices. Soil Tillage Res. 2004, 79, 131-143.

33. Ros, M.; Pascual, J.A.; Garcia, C.; Hernandez, M.T.; Insam, H. Hydrolase activities, microbial biomass and bacterial community in a soil after long-term amendment with different composts. Soil Biol. Biochem. 2006, 38, 3443-3452.

(C) 2011 by the authors; licensee MDPI, Basel, Switzerland. This article is an open access article distributed under the terms and conditions of the Creative Commons Attribution license (http://creativecommons.org/licenses/by/3.0/). 